\title{
The EGFR Polymorphism Increased the Risk of Hepatocellular Carcinoma Through the miR-3 196-Dependent Approach in Chinese Han Population [Corrigendum]
}

Zhang L, Li X, Lu J, et al. Pharmgenomics Pers Med. 2021;14:469-476.

Page 470, Materials and Methods, Clinical Samples, second sentence, the text "All blood samples are taken from Liyang People's Hospital during
March 2009 to August 2019" should read "All blood samples are taken from Liyang Branch of Jiangsu Province Hospital and Jiangsu Province Hospital during March 2009 to August 2019”.

The authors apologize for this error.

\section{Publish your work in this journal}

Pharmacogenomics and Personalized Medicine is an international, peer-reviewed, open access journal characterizing the influence of genotype on pharmacology leading to the development of personalized treatment programs and individualized drug selection for improved safety, efficacy and sustainability. This journal is indexed on the American Chemical Society's Chemical Abstracts Service (CAS). The manuscript management system is completely online and includes a very quick and fair peer-review system, which is all easy to use. Visit http://www.dovepress.com/testimonials.php to read real quotes from published authors. 